Gábor Egry

\title{
Regional Elites, Nationalist Politics, Local Accommodations. Center-Periphery Struggles in Late Dualist Hungary
}

The history of empires is currently enjoying a revival and has now become the subject of intensive scholarly interest. A significant example of the growing literature on „New Imperial History", ${ }^{1}$ is Pieter M. Judson's work on the Habsburg Empire. This book also typifies the new wave of historiography on the history of the Habsburg realm, a trend that has also led to a thorough reconsideration of Eastern Europe's not too distant past. $^{2}$ The literature on the dualist state however, tends to replicate its peculiar structure, and the works barely attempt to connect the history of its two halves. There is good reason and justification for this approach; Hungary and the ,provinces represented in the Reichsrat” (Cisleithania; or, in short, Austria) had profoundly different structural characteristics from the perspective of their state structures. The Austrian half was a conglomerate of provinces with various administrative traditions: these were partial legislations that retained (or, relative to the neo-absolutist times, regained) a certain degree of autonomy even after 1867 . Hungary, on the other hand, was supposed to be a unitary state with a unified administration and legal system. Furthermore, while there was no national movement in the Austrian half that would have encompassed all of the provinces to make it a starting point of overall nationalizing attempts, Hungary was imagined as a nation state by its elites with all of its nationalizing consequences. ${ }^{3}$ But questions that have rarely been raised thus far now seem pertinent and necessary in order to address the mechanics of integrating two states within a common imperial framework. Further questions arise to consider how the co-existence of disparate state models affected both components, and, finally, one should ask whether this distinction is meaningful at all.

\footnotetext{
${ }^{1}$ Ulrike von Hirschhausen, New Imperial History? Programm, Potenzial, Perspektiven, in: Geschichte und Gesellschaft 41 (2016), pp. 718-757.

${ }^{2}$ Pieter M. Judson, The Habsburg Empire. A New History, Cambridge, Mass. 2016; Gary B. Cohen, Nationalist Politics and the Dynamics of State and Civil Society in the Habsburg Monarchy, 1867-1914, in: Central European History 40 (2007), pp. 241-278, see also the numerous works on national indifference.

${ }^{3}$ Wesley Hiers/Andreas Wimmer, Is nationalism the cause or the consequence of the end of empire?, in: John A. Hall/Sinisa Malesevic (eds.), Nationalism and War, Cambridge 2013, pp. 212-254.
} 
While an ,imperialist” approach should necessarily reckon with the dual character of the Monarchy, it still faces another challenge: if Hungary was in fact a nationalizing (or even just a would-be nation) state, how then might one extend the scope of the analysis of the empire to its history? Thus, it is hardly surprising that historical works tend to limit their focus to one half or the other, or even take a narrower approach. An imperial history could hardly rely on a comparison of the two halves, as it would immediately question the imperial framework. Not even Judson's book could encompass the entirety of the Monarchy. His top-down approach - the analyses of how the notion, idea, and practices of the empire saturated regional and local communities from above, and how societies were transformed by it - falls understandably short of an integrated history. ${ }^{4}$ Achieving such an integrated history is a burdensome task when faced with the challenges of conflicting structures and viewpoints; these challenges include the filtering of the imperial through the ideas of Hungarian and royal within Hungary, the insistence of the dominant rhetoric on the separate Hungarian national statehood, as well as the presentation of politics as unitary rather than fragmented in space and along societal divisions..

One notable exception to this trend is Benno Gammerl's book on citizenship legislation, ${ }^{5}$ which attempts to compare the Habsburg Monarchy with the British Empire. Throughout this effort Gammerl could use Hungary as an object of comparison, with Canada as its counterpart, thus successfully locating it within the imperial framework. In this case, however, Gammerl glosses over the peculiarities of the dualist structure. Furthermore, Gammerl analyzes the evolution of citizenship legislation, a subject that circumvents the problems other works faced insofar as it tackles a legal institution that was unitary within at least one component element of the empire and not uneven as the more uneven social structures or politics.

In this paper, I propose an alternative approach to Hungary's perception as a nation-state, also as a means of bringing together the analyses of the two halves of the Empire. I will argue that Hungary alone was more of an imperial structure than it is customarily acknowledged to have been. Especially the handling of center-periphery relations was analogous with the practice of empires, and taken together with some crucial characteristics of the Hungarian state - most significantly with its multi-ethnic nature - these characteristics enable us to speak here of an

\footnotetext{
${ }^{4}$ Judson, The Habsburg, pp. 1-15, 333-384.

${ }^{5}$ Benno Gammerl, Untertanen, Staatsbürger und andere. Der Umgang mit ethnischer Heterogenität im Britischen Weltreich und im Habsburgerreich 1867-1918, Göttingen 2010.
} 
empire. Such an interpretation would be all the more legitimate since New Imperial History regards even the more homogeneous successor states as mini- or quasi-empires. ${ }^{6}$

The existence of such an ,informal" or ,hidden” imperialism was on the one hand the result of a historical legacy. But it was also the result of the challenges Austria-Hungary in general, and its Hungarian component state in particular, faced around the turn of the 20th century. They emerged in the context of modernization, national mobilization, mass politics, and the reconfiguration of the relationship between state and citizen. ${ }^{7}$ Not surprisingly, one of these elements was nationalist politics (including Hungarian nationalism as well), the rise of which affected the balance of the empire too. The next matter was the issue of modernization in a state of uneven development. ${ }^{8}$ In certain regions of Hungary in the decade before WWI (for example in Transylvania) a premodern economy co-existed with the chance to ride the wave of the second industrial revolution through exploitation of natural resources such as natural gas. Both backwardness and the chance of a leap forward resulted in development plans that were accompanied by ideas of social reform and transformation, but they were hard to realize without the central government's intervention. ${ }^{9}$

Competition with the new nation states that often seemed to be more efficient than the traditional, continental, and dynastic empires was another important factor. The resulting mutual adaptation process between empires and nation states generated social, economic, and political tensions and both the center and the peripheral locals had to find ways to manage them. Thus, the efficiency of the state in managing its peripheries became crucial, and presented a third challenge.

Here I will use the examples of center-periphery relations to show the significance of imperial practices and their interrelatedness with the new challenges. The three models I intend to present are (1) self-colonizing based on feudal traditions, a method that reconciled centralization with

\footnotetext{
${ }^{6}$ Hirschhausen, New Imperial, p. 753.

${ }^{7}$ Cohen, Nationalist.

${ }^{8}$ Andrew C. Janos, The Politics of Backwardness in Hungary 1825-1945, Princeton 1982.

${ }^{9}$ Balaton Petra, A székely akció előzménye és története, In: Molnár Vilmos/Lövétei Lázár László/Botár Emőke (eds.), Székelyföld Évkönyv 2010, Csíkszereda 2010, pp. 181-207.; Bárdi Nándor, Az erdélyi magyar (és regionális) érdekek megjelenítése az 1910-es években. Az Erdélyi Szövetség programváltozatai, in: Magyar Kisebbség 8 (2003) 3-4., pp. 93-105.; Zsolt K Lengyel, Niedergang, Wiederherstellung, Neugestaltung, Zusammenbruch: Ungarische Reform- und Zukunftsentwürfe für Siebenbürgen am Vorabend und während des ersten Weltkrieges, in: Heppner Harald (Hrsg.), Umbruch mit Schlachtenlärm. Siebenbürgen und der Erste Weltrkieg, Köln/Wien/ Weimar 2016, pp. 53-112.
} 
practical regional autonomy, while making ethnic boundaries insignificant within local society; (2) a regionalist movement that has grown out of a desire for modernization and the intention to face the challenge of strengthening minority national movements; and (3) the reorganization of the titular nation at the local level as an ethnic minority. While some of the aspects of these models were common or at least similar, they were still distinct varieties, and offered different solutions for the same question: how to promote and represent local and regional interests in an increasingly unitarianist and nationalizing multi-ethnic state against the backdrop of uneven development and national mobilization?

\section{The Hungarian „Empire” and its peripheries around 1900}

The definition of an empire - as a specific, distinguishable form of statehood - is just as contested as most concepts that attempt to generalize phenomena on the basis of often diverse, and sometimes disparate cases. For a long time, empire either constituted a colonial empire ruled from a metropolitan center, or a dynastic conglomerate of states, provinces, kingdoms and cities accumulated by a lineage of rulers on the basis of a wide variety of entitlements to the respective units. Therefore, colonial empires of modern European states were easy to juxtapose with the ailing dynastic, continental ones. Recent sociological works and historiography, however, emphasizes that despite all of their differences, both types of empires represented a common, distinct form of statehood, one that was based on differentiated rule from a metropolitan center over diverse territories, all of which constituted a periphery in its relation to this center, whatever its position vis-a-vis the other component units was. ${ }^{10}$

Differentiated rule was based not solely upon the legal statutes of the parts of the empires, but also on the active cooperation of local and regional elites. Essential for the establishment of imperial order, their knowledge of local culture, habits, customs, and laws was indispensable for the rulers. Thus, these social groups gained agency to impact the nature, means, and aims of imperial rule (and the agency to impact the center itself) as well as the chance to negotiate their positions within the imperial structures. ${ }^{11}$ Empires also frequently relied on imperial figures, certain personalities, whose knowledge - technological, political, academic, etc. - and whose

\footnotetext{
${ }^{10}$ Jane Burbank/Frederick Cooper, Empire in World History. Power and the Politics of Difference, Princeton/Oxford 2010, p. 8, pp. 16-17; Charles Meier, Empires or Nations? 1918, 1945, 1989, in: Carl Levy/Mark Roseman, Three Postwar Eras in Comparison. Western Europe 1918, 1945, 1989, Ashgate 2002, pp. 41-67, esp. pp. 46-47.

${ }^{11}$ Hirschhausen, New Imperial, pp. 730-734.
} 
mobility enabled them to move across the often vast imperial space and connect parts of the empire, while facilitating the transfer of imperial knowledge, too. They were frequently also interlocutors between center and periphery, whose role was to balance conflicting interests. ${ }^{12}$

Finally, empires gradually adapted to the models provided by the rival nation states, while the latter also borrowed from the repertoire of empires. This mutual adaptation process led to the nationalization of empires and the imperialization of nation states, a process that manifested itself in reforms such as broadening suffrage, universal conscription in empires, or colonial fantasies of nation states. ${ }^{13}$ In the Habsburg Monarchy it happened against the backdrop of democratization, which meant not just reforms of the electoral law, but also and mainly the spread of civic associational life, as well as a gradual engagement of ever larger segments of society with politics, formally or, often, informally. The result was the growing influence of society on political decisions, although this influence was often exerted through informal means, influencing the bureaucracy at different levels of the administration. ${ }^{14}$

Hungary around 1910 fitted most of the criteria of an imperial state. Behind the smokescreen of the ever louder rhetoric of a unitary nation state, ${ }^{15}$ it still exhibited many features of a dynastic territorial conglomerate. Not only was dualist Hungary the result of the unification of a series of administrative units previously under the direct authority of Vienna (the Grand Principality of Transylvania; the territory of the border regiments; Croatia, ruled directly by the Viennese government after 1849; the Banat, abolished in 1778, revived as part of the Voivodina between 1850 and 1860), but dualist Hungary was also the product of lasting effects of the disunity of the reconquered country (after 1718) and that of the feudal legal system, which persisted well into the late $19^{\text {th }}$ and early $20^{\text {th }}$ centuries. The most notable among them was the application of the neo-absolutist Austrian Civic Code (issued in 1852) in Transylvania, a practice that was finally abolished only by the communist regime, ${ }^{16}$ but the abolishment of privileged groups (in Spiš/Szepes, the Jász-Kun and Hajdú districts) and territorial units (the Saxon

\footnotetext{
${ }^{12}$ Ibid. pp. 734-737.

13 Jörn Leonhard/Ulrike von Hirschhausen, Empires und Nationalstaaten im 19. Jahrhundert, Göttingen 2009, pp. 12- 3, pp. 107-109.; Hirschhausen, New Imperial, 753.

${ }^{14}$ Cohen, Nationalist.

${ }^{15}$ Cieger András, A hatalomra jutott liberalizmus és az állam a dualizmus első felének magyar politikai gondolkodásában, in: Századvég 20 (2001), pp. 95-118.

${ }^{16}$ Magdolna Mária Vallasek, Az 1918. évi egyesülést követõ jogegyesítési folyamat kérdése Romániában, Magyar Kisebbség 9 (2004) 2-3, pp. 573-590.
} 
"Nationsuniversität," the Székely Seats) did not happen until the 1876 administrative reform, either. Even after this date, some of these units continued to exist after some reform. The Transylvanian Saxon "Nationsuniversität" was, for example, transformed into a representative body whose members were elected by the inhabitants of the former Königsboden per parliamentary electoral suffrage, and it was responsible to manage the huge property, mainly forests in the Carpathian mountains with only one condition: the revenues had to be disbursed for cultural and educational purposes for the inhabitants of the former Saxon autonomy. ${ }^{17}$

On the other hand, the unification did not start with 1867 and it was not solely the result of Hungarian nation-building efforts. Already the enlightened absolutist rulers attempted to curtail feudal rights, unify administration and legislation, and Joseph II established a unitary administrative system for the whole territory of Saint Stephen's Crown. Still, the early dualist administrative reforms were different from the Josephin precursors as they established a unitary state of the Hungarians, and despite all of the setbacks caused by the leftovers from the feudal era, its goal was to develop a unified nation-state. The struggle with „feudalism,” however, did not abate with the reforms; instead the fight of feudal rules, norms, institutions, customs, and behavior was a permanent theme of politicians who wished to further modernization. ${ }^{18}$ Whatever pretensions its leaders had, Hungary was less a unitary France of the East than it was a country in the phase of rapid modernization and reform that affected society very unevenly, leaving broad segments of this society behind and often preserving informal rules and institutions. ${ }^{19}$

The realities of Hungary left their imprint on center-periphery relations too. The three cases outlined in this chapter have their roots in three different local contexts that, nevertheless, shared important commonalities. All of them originated from the existence of distinct, privileged groups prior to the abolishment of feudal privileges and the administrative reforms (nobility, Székely estates, Saxon "Nationsuniversität"). The cases were characterized by extreme peripheral situation (including social and physical distance, backwardness, or peculiar social structure), and two of them figured in areas only recently incorporated into Hungary. From this perspective, the three models of emerging differentiated rule reflected different attempts to cope with the

\footnotetext{
${ }^{17}$ Carl Göllner, Die Siebenbürger Sachsen in den Jahren 1848-1918, Köln/Wien/Weimar 1998.

${ }^{18}$ Cieger, A hatalomra jutott.

${ }^{19}$ Janos, The Politics, 84-148.
} 
transition from the feudal system to the modern, nationalized society, in order to overcome the imperial heritage.

The county Maramureș (Máramaros, Maramuresch), situated in the northeastern corner of the country, surrounded by high mountains, and hardly accessible from the central plain or from neighboring Transylvania, was a multi-lingual and multi-religious area (Roman and Greek Catholics, Calvinists, Orthodox believers, and Jews, speaking Hungarian, Romanian, Yiddish and Ruthenian lived in the cities and valleys) dominated by a nobility bound with extremely tight kinship networks. This nobility - again multi-lingual and multi-religious - had a monopoly on the county and local administrations, a strong presence in the judiciary, while the personnel of the education and the local organs of the central government had more diverse origins. While the noble clans established a firm hold on the political representation in the county organs (county congregations, executive committees, city councils, etc.), these institutions were important channels of co-optation into this closed elite. This was especially true for education. Professors of the local law school (a Calvinist, college-level institution), and the high schools were readily invited into the political bodies and were offered leadership positions in the most important civic associations. $^{20}$

The second example, Târgu Mureș (Marosvásárhely, Neumarkt am Mieresch) was the historical center of the Székelyland, once one of the three feudal estates in Transylvania. It was an administrative and educational center, and as the Székely people became the basis of the Hungarian war of liberation in Transylvania in 1848-49, it gained symbolic importance, too. Around the turn of the century industrial development started due to the city's advantageous location, and it gradually changed the social composition of the local society, adding a new stratum of industrial workers. But the rural hinterland of Târgu Mureș and the whole Székely region further to the East remained hopelessly backward. ${ }^{21}$ With the intensifying RomanianHungarian national conflict in the background, ${ }^{22}$ local politicians and the government initiated a series of so-called "Actions" aimed at giving impulses to economic and social development.

\footnotetext{
${ }^{20}$ Cieger András, Érdekek és stratégiák: a helyi politikai elit érdekérvényesítési lehetőségei a kárpátaljai régió vármgyébien a dualizmus időszakában, in: Korall 13 (2003), pp. 87-105, esp. p. 90, pp. 92-94, p. 100.

${ }^{21}$ Pál Judit, Városfejlődés a Székelyföldön 1750-1914. Csíkszereda 2003.

${ }^{22}$ Keith Hitchins, A nation affirmed: The Romanian national movement in Transylvania, 1860-1914, Bucharest 1999.
} 
Industrial investment, better agricultural production techniques, and cheap credit were the main tools of this attempt.

At a first glance, the city of Brașov (Brasó, Kronstadt) represented a world apart from Maramureș or the Székelyland. It was a modern, thriving city, with factories, tramlines, paved roads, street lighting, modern administrative buildings, and numerous civic associations. But its society was divided along ethnic lines, a division that originated from its feudal past, when only Saxon citizens had political and property rights. A few decades of civic equality could not erase the resulting social differences and hierarchy, and, with the help of the restrictive electoral census, Saxons easily retained their dominance over local politics and administration, although by 1910 they were numerically the weakest among the three nationalities living in Brașov. ${ }^{23}$ It was especially painful for the Hungarian politicians, who had to face a dire reality: most Hungarians in the city belonged to the lower social strata, and those who had better social positons were mainly state officials. The dream of millennial Hungary encountered significant difficulties here, where an educated, prosperous, non-Hungarian elite successfully pursued its own national goals, and even the local Romanians were in a better position than the Hungarians. ${ }^{24}$ However strong the Hungarian nation state was or wished to be, it had to face serious difficulties in these peripheral regions.

\section{Three models of differentiated rule}

\section{Maramureș and self-colonization}

The three models emerging out of the various contexts of center-periphery relations were the conscious self-colonization carried out by the elite in Maramureș, a full-fledged regionalist attempt in Transylvania that also tried to address the ascendancy of the Romanian national movement, and minority politics and nation-building realized by the local group of the dominant (or titular) Hungarians in Brașov. In this subchapter I will outline the most important features of these models, how they reconfigured local society, how they settled relations with the

\footnotetext{
${ }^{23}$ Varga-Kuna Bálint, The Monumental Nation. Magyar Nationalism and Symbolic Politics in Fin-de-siècle Hungary, New York/Oxford 2016; Harald Roth, Kronstadt in Siebenbürgen. Eine kleine Stadtgeschichte. Köln/Weimar/Wien 2010.

${ }^{24}$ Varga-Kuna Bálint, The Monumental.
} 
government (the center), how they were related to the political struggle with national movements and their nationalism, and, finally, how they shaped Greater Romania, emerging from the ruins of dualist Hungary.

Maramureș had a peculiar social landscape that determined politics and administration in the region. The tight kinship bonds connected an otherwise diverse nobility that nurtured a regional identity, too. These bonds transcended ethnic boundaries, which was otherwise not insignificant, but despite the - often bellicose - rhetoric of Maramureș politicians in the county congregation, the nobility offered solidarity to all its members irrespective of ethnicity, spoken language, or religion. Solidarity, in this case, usually meant employment and advancement in the administration or in the judiciary, and participation and cooperation in the associational life of the county. Those who were part of this elite of noble origin also received symbolic recognition in various forms, including laudatory obituaries. ${ }^{25}$

Nevertheless, such a close-knit variety of the rule of the nobility was unusual in most part of the country, especially in the thriving urban centers, and it established a social distance with the center. But this social distance was reinforced at the lower end of the social ladder as well. Maramureș was the home of a large, Orthodox Jewish population, who were on the whole rather poor, and a significant part of which was active in agriculture; this was a peculiar social profile for Jews in Hungary.

The noble elite of Maramureș used several means for preserving its dominant position; this process involved a certain amount of adaptation to the requirements of modernization. The first of those was self-reproduction through education, most notably through law degrees. Graduating from a law school also meant a degree in Staatswissenschaft (Study of the state), a rather symbolic one, but it still represented an exclusive claim by law graduates on positions in the administration. Many of the noble offspring from Maramureș attended the Budapest or Kolozsvár (Cluj, Klausenburg) universities, but the county had its own law school, too. The Calvinist church maintained a high school and a so-called Academy of Law (in fact a law college) in Sighetul Marmaţiei and both institutions were quite popular ones. Not only Calvinist

\footnotetext{
${ }^{25}$ Cieger András, Érdekek, pp. 92-94.
} 
families sent their children there, but Jews and Greek Catholics, too - the latter despite the fact that the language of instruction was Hungarian. ${ }^{26}$

As the graduates from the law school were mostly family members of the local nobility, and as they sought employment in the county and city administrations, it was not surprising that these institutions conferred significant prestige on their teachers, even if they were from without the region. Gergely György, for example, was born in Satu Mare (Szatmárnémeti, Sathmar), graduated in Budapest, and started to teach in Sighetul Marmației in 1900 as assistant professor after he spent a year as a judge. From 1902 he was full professor, and beginning in 1914 he was the deputy director of the Academy of Law. The prestige of this position is reflected in further positions he held. He was, among others, chair of the education section of the Maramureș County Cultural Association, member of the board of trustees at the local civic boys' school, member of the board of directors at the state teacher training school in Sighetul Marmației, member of the permanent committee of the county congregation, and a member of the city council. He was also lay superintendent of the Maramureș Calvinist Diocese, and very active in professional and cultural associations at national level, too. ${ }^{27}$

Gergely was not alone among the seven permanent professors (in 1918) to hold important social and political positons beyond the walls of the school. Szatmár, however, was relatively close to Maramureș, a neighboring county, and this proximity certainly made his co-optation swifter. For example, his two colleagues who came to Sighetul Marmației from Hungary proper were never invited to play similar roles in any local association, while his fellow Szatmárian, János Lányi also got elected to the permanent committee of the county and to the city council. ${ }^{28}$

A different pattern is, however, discernible among the more numerous secondary education teachers, whose geographic origin was more mixed, too. Of seventeen teachers in 1918 only two were of local origin, and three were from the neighboring counties. Although the most

\footnotetext{
${ }^{26}$ Balogh Béla, A máramarossziget református líceum története, Debrecen 2013.

${ }^{27}$ A máramarosszigeti ref. lyceum jogakadémia, főgimnázium és internátus értesítője az 1916-17-es tanévről. Máramarossziget 1917; A máramarosszigeti ref. lyceum jogakadémia, fögimnázium és internátus értesítője az 191617-es tanévről. Máramarossziget 1918; Máramarosi Közmüvelődési Egylet, Máramaros 8. July 1917, p. 1; Városatyák választása, Máramaros, 20. December 1917.

${ }^{28}$ A máramarosszigeti ref. Lyceum jogakadémia, főgimnázium és internátus értesítője az 1916-17-es tanévről. Máramaroszsiget 1917; A máramarosszigeti ref. Lyceum jogakadémia, fögimnázium és internátus értesítője az 1917-1918-as tanévről, Máramarossziget 1918; A máramarosszigeti ref. Lyceum jogakadémia, főgimnázium és internátus értesítője 1918-1919-es tanévről, Máramarossziget 1919.
} 
prestigious among them was Péter Juhász, born in Sighetul Marmației in 1873, practically all the others found their way into local professional, cultural, and economic associations, and six out of the eight who held political positions were from without the county. ${ }^{29}$

But firm control over the local institutions was only one factor behind this peculiar power context, and it would have been insufficient alone to preserve the dominant role of the noble clans. It was the support of the central government that was necessary for the perpetuation of their dominance, and the Maramureș elite, just like their counterparts in other counties of the region that is today Karpatho-Ukraine, used a strategy that resembled colonial relations. It was a conscious strategy, based on detaching - as much as it was possible - local from national politics. At the national level the local elite that was capable to deliver the votes from the region, always aligned itself with the governing party, regardless of whatever its political orientation was. The local elite usually invited one or two prominent politicians, prospective ministers or state secretaries, to represent the Sighetul Marmației constituency, while the other MPs were selected from the local noble families. The Lord Lieutenant, nominally the representative of the government also always had local roots, and in 1917 the local newspaper explicitly called it a lasting tradition that all previous governments observed. ${ }^{30}$ Romanians had a firm position within this settlement. They were usually eligible for the role of MPs aligned with the government party and held high-level positions within the county administration. Romanians were important for the local nobility because of their significant role in the Romanian Greek Catholic church, too. The Mihalis from Apșa (Apsa) sent MPs to Budapest (Tivadar/Teodor, Péter/Petru) and also gave an archbishop to the church in the person of Victor Mihali. ${ }^{31}$

The „deal”, therefore, brought mutual advantages. In exchange for parliamentary support and public alignment with the government's politics the local elite retained control over the administration and the allocation and distribution of resources. Within this framework there was no place to express deviation from the national politics, Maramureș county and its congregation supported rhetorically the building of a unitary, modern, Hungarian nation state. But within the

\footnotetext{
29 Ibid.

${ }^{30}$ Cieger, Érdekek, pp. 90, 100; Az új főispán Máramarosszigeten. Máramaros 22. Július 1917.

${ }^{31}$ Ovidiu-Emil Iudean, Between National Solidarity and Local Interests. The Pro-Governmental Political Orientation of the Romanians in Hungary (the End of the 19th Century the Beginning of the 20th Century), in: Bratanis et. al. (eds.), Infusing Research and Knowledge in South East Europe. 7th annual South East European Doctoral Student Coferece, Thessaloniki 2012, pp. 873-887.
} 
county it rather meant the stability of a pre-modern elite that could rely on material and political support from Budapest while pursuing its local goals. Maramureș elites had to perform selfsubmission to the center, but were left with a free hand within their much smaller realm. ${ }^{32}$

But the real strength of this arrangement was revealed after the dissolution of the Monarchy. When the Romanian troops arrived at Maramureș, and after they declared the sovereignty of the King of Romania, the center-periphery relations were shaken. Although, for a while, the local institutions and figures tried not to severe connections with Budapest, it turned out to be an impossible task. State-owned institutions were transferred to the Romanian state that imposed new rules within, while the Calvinist schools lost their state subsidies that effectively kept them above water before 1918. Due to various reasons - most of them rather petty and personal ones authorities finally closed the Calvinist high school and the Academy of Law and the latter was relocated to Hungary. ${ }^{33}$

But behind the facade of quick and sweeping Romanianization, the former arrangements held up surprisingly well. The basis for such an outcome was the continuing hold of the local elite on the administration. This continuation was relatively easy because of the integration of Greek Catholics prior to 1918. Most of the public servants of the county in 1925 were public officials already before 1918, although sometime they changed their names to more Romanian-sounding ones. Those who occupied the higher, and consequently more political, positions, figured in the local multi-ethnic society before 1918 , as well. ${ }^{34}$

It is, thus, not surprising that while the Academy of Law and the Calvinist High School challenged the authorities over their subsequent restrictive decisions, they received support from the county administration, which tried to play the role of mediator between Bucharest and the Hungarian institutions. Gergely György himself argued that the county administration was

\footnotetext{
${ }^{32}$ Cieger, Érdekek, p. 100

${ }^{33}$ Bárdi Nándor, Otthon és haza. Tanulmányok a romániai magyarság történetéböl, Csíkszereda 2014, pp. 91-95; Balogh, A máramarosszigeti; Arhivele Naționale Secția Județeană Maramureș, Liceul Reformat din Sighet (ANSJ $\mathrm{MM})$.

${ }^{34}$ One example of such amphibious behavior was Dán György/Gheorghe Dan. He held the position of the secretary of the Lord Lieutenant before 1918 and became vice prefect after 1920. Magyarország tiszti cím- és névtára az 1917. évre. Budapest 1917; Calendarul administrativ pe 1925. Cluj 1925, p. 296.
} 
willing to help them because most of those who occupied positions after 1918 were graduates of the Academy of Law. ${ }^{35}$

Even after the closure of the two institutions, Maramureș displayed similar characteristics as before 1918. The prefects (the peers of the Hungarian Lord Lieutenants) were selected during the long tenures of liberal governments (1922-1926, 1927-1928, 1933-1937) from the local Romanian families, quite often from the Mihalis. The press reported not infrequently on ,,interludes” that put Hungarian cultural practices on public display - by Romanians. ${ }^{36}$ Maramureș Romanians seemed to be more tolerant towards Hungarians than the nationalizing efforts of the state would have presupposed. ${ }^{37}$ And finally, when the county was reannexed to Hungary in 1940 its new Lord Lieutenant was a Romanian, Flavius Jurca, who served as a public official before 1918 (he even had a publicized duel), continued his career uninterrupted after the Romanian takeover, and who was generally considered to be one of the members of the Mihali clan. $^{38}$

\section{Transylvanian regionalism}

Given the scope of its activities and goals it is hardly surprising that Transylvanian regionalism represented a very different pattern of center-periphery relations. While the Maramureș noble families were content with preserving their dominance in a small and distant region, and happy to reap some of the fruits of modernization, those, who around 1910 started to organize a new movement that raised the flag of Transylvanian interests, intended to fend off two perceived threats to Hungarian supremacy in the province: the growing strength of the Romanian national movement, and the very limited success of (Hungarian) modernization so far. ${ }^{39}$ But the

\footnotetext{
${ }^{35}$ AN SJ MM Liceul reformat dosar 854, f. 28-29; dosar 868, f. 68.

${ }^{36}$ Máramarosban magyarul mulatnak. A román alispánt azzal vádolják, hogy boros fejjel a magyar himnuszt énekelte, in: Pesti Napló, 20. Oktober 1935, p. 9.

${ }^{37}$ Máramaros megértő szelleme. Máramaros, 20. Juni 1929.

${ }^{38}$ Ablonczy Balázs, Teleki Pál nemzetről és társadalomról - visszacsatolások előtt és után, in: Fedinec Csilla (ed.), A nemzet a társadalomban. Budapest 2004, pp. 151-172, p. 164.

${ }^{39}$ On the regionalists see Bárdi, Az erdélyi; Egry Gábor, Regionalizmus, erdélyiség, szupremácia. Az Erdélyi Szövetség és Erdély jövője, 1913-1918, in: Századok, 147 (2013) 1, p. 3-32; K. Lengyel, Niedergang; on Romanians see Hitchins, A Nation; Ovidiu Emil Iudean/Alexandru Onojescu, Politics, nationalism, and parliamentarism. The Romanian representatives in the Budapest Parliament (1861-1918), in: Transilvanian Review, 22 (2013) 4, pp. 3-16. On modernization see Egry Gábor, Nemztei védgát vagy szolíd haszonszerzés? Az erdélyi szászok pénzintézeti rendsezre és a nemzeti mozgalom kapcsolata a 19. században, 1835-1914, Csíkszereda 2009; Balaton, A székely. A literary portrayal from regionalist perspective Miklós Bánffy, The Transylvanian Trilogy: They Were Counted. New York 2013.
} 
immediate reason to establish a new organization, the so-called Transylvanian Alliance, was the victory of István Tisza’s Party of National Work at the elections in 1910.

Tisza, probably the most intensely hated figure in late dualist Hungarian politics, returned victoriously after four years outside parliament, where he confined himself when his liberal party was ousted from government - after more than thirty years in power - in $1905 .{ }^{40}$ His victory in 1910, although rooted in violence and corruption, left the fragmented opposition with only a handful of representatives in the parliament. In Transylvania, it meant that just a fraction of the region's MPs opposed Tisza, while before 1910 there was not one liberal MP from the province. More importantly, Tisza's party seemed to make a breakthrough at the county level, too. In 1910 they captured the symbolic Kolozsvár city congregation that was previously held by the opposition for decades. The opposition, shattered from the series of failures, tried to find alternative means of mobilization and challenging the government, and regionalism seemed to be a potent way to do it. ${ }^{41}$

When the regionalists, who had floated their ideas since 1910 in the press, finally decided to establish their organization, the Transylvanian Alliance, it became a rallying point for Tisza's opposition. Most of their parliamentary representatives joined the organization (13 MPs), alongside with six former MPs of the opposition, and only one of the pro-Tisza MPs was invited. But the Alliance, managed by István Apáthy, a professor of biology (genetics) at the University of Kolozsvár, and a close friend of Count Mihály Károlyis, was not just camouflage for politicians who were threatened with becoming irrelevant at the national level. The main reason for the Alliance's existence was its members' conviction that Transylvania faced grave dangers and challenges (in the form of a revived Romanian nationalism that was accompanied by the rapid development of a Romanian middle-class, often at the expense of the Hungarian gentry, and in the form of lasting backwardness of the Hungarian-inhabited regions, whose targeted development that started around 1900 had not yielded significant results so far), and the central government was not ready to acknowledge or capable to resolve them, due to their lack of knowledge of the region's realities. ${ }^{42}$

\footnotetext{
40 Vermes Géza, Tisza István, Budapest 2001.

${ }^{41}$ Egry, Regionalizmus, pp. 4-7.

${ }^{42}$ Bárdi, Az erdélyi; Egry, Regionalizmus, p. 8., pp. 13-14.; K. Lengyel, Niedergang, pp. 62-71.
} 
The combination of the prospect of lasting irrelevance in national politics and the real concern over the problems of Transylvania gave way to the idea of reconfiguration of the centerperiphery relations, relaxation of the centralization of the Hungarian state, and a specific treatment of Transylvania by the central government. While the alliance never explained how it would have imagined the new, regionalist administration of the province, it gave elaborated programs on how to resolve the impending problems. ${ }^{43}$

Without going into details, let it suffice to outline how the regionalists wanted to reconfigure center-periphery relations. While they advocated further state-driven development efforts in the Székelyland, their most important demand was larger influence of local politicians on the decisions concerning Transylvania. The problems, they argued, could only be resolved by people who had the necessary knowledge on local conditions, who were aware of the real nature of threats, and who could organize the region's Hungarian society into a unitary one which would work for the common goal of modernization: educating and elevating the peasantry, fostering a new industrial base with the help of the natural gas resources, building new railways, and spreading modern agricultural techniques. Logically, the administration needed a thorough reform, too; this reform was mainly professionalization, just like politics was broadening suffrage. Regionalists demanded unconditional support of the government for their own projects as it was thought to be the only way to save the province from falling into the hands of the Romanians, but, on the other hand, at least until 1917, they did not advocate for the legal discrimination against Romanians. ${ }^{44}$

With this reasoning they cunningly avoided the task of elaborating on the nature of provincial self-governance, not least because the members were divided in this regard. The farthest they went was in 1917 with the idea of the appointment of a government commissary with extensive executive power who would have acted as a governor. Nevertheless, some members of the Alliance publicly advocated a kind of regional autonomy, and the arguments employed in this regard resembled the classic argumentation of most regionalist movements that aimed to distance a territory from a country, and not on the basis of ethnic difference. The roles of the center and periphery were reversed as far as the periphery was portrayed as the authentic region in national terms, while the regional elites claimed to act as the spearhead of the nation against the

\footnotetext{
${ }^{43}$ For more details see Bárdi, Az erdélyi.

${ }^{44}$ Egry, Regionalizmus, pp. 9-13.; K. Lengyel, Niedergang, pp. 71-84.
} 
minorities. ${ }^{45}$ As this conflict was posited as the one deciding the fate of the nation, they could invoke unconditional support from the center, without its intervention, due to their far superior knowledge of the enemy. In this sense, it was not simply regionalism, but also a variety of nationalism: theirs was a subsidiaristic nationalism that upheld the unity of the nation, but still demanded the relocation of the decisions from the center to the periphery, and it attributed the most important national roles to the regional elite. ${ }^{46}$

The Transylvanian Alliance was not simply an opposition organization. After Tisza's fall in 1917, its members suddenly gained influence in the central government, with some of them becoming ministers (Gábor Ugron, minister of interior), while others became influential lobbyists within the new governing parties. Henceforth, their ideas started to shape government policies that led to a more discriminatory action against Romanians. ${ }^{47}$ But even before the regionalist came to power, it was already a serious challenge to the central government, especially after the opposition, aligned with regionalism, regained its positions in important county and city congregations, in Cluj and Târgu Mureș. While Tisza was not ready for formal concessions, he still applied methods familiar from imperial practices to strike a balance. He sent a young politician filled with aspirations to serve as an interlocutor.

György Bernády ${ }^{48}$ was an atypical figure in county political life. He was a pharmacist and not a lawyer, and did not belong to the typical gentry environment of the county politics. After serving as a liberal MP between 1896 and 1901, he was selected for the role of mayor of Târgu Mureș that he held between 1902 and 1912. The county and the city was among the strongest bastions of the opposition, and in 1913 Bernády seemed to be the suitable person to mediate between central government and local opposition. The city was in a phase of rapid modernization during Bernády's tenure as mayor, and this could not happen without financial help from the government. This decade coincided with the electoral terms of pro- and anti-Tisza governments, and Bernády had to establish contacts with both political currents in order to secure the necessary

\footnotetext{
${ }^{45}$ Anssi Paasi, The institutionalization of regions: a theoretical framework for understanding the emergence of regions and the constitution of regional identity, in: Fennia. International Journal of Geography (1986) 1, pp. 105146.; Miroslav Hroch, Reflections on the Role of History in (Re)constructing Regional Identity, in: Steven G. Ellis et al. (eds,), Frontiers, Regions and Identities in Europe. Pisa 2009, pp. 1-14.

${ }^{46}$ More on this see Egry, Regionalizmus, 25-28.

${ }^{47}$ For details see Egry, Regionalizmus.

${ }^{48}$ For Bernády’s biography see: Fodor János, Bernády György. Politikai életrajz. Marosvásárhely-Kolozsvár. This part is based on Fodor's elaborate work.
} 
funds. It is therefore not surprising, that after 1913, as the newly appointed Lord Lieutenant of the city, he successfully cooperated with Tisza's opposition in local politics. ${ }^{49}$ While he still deviated from the political mainstream of his city and county, he could bridge the gap between center and periphery and channel funds into an opposition city that, unlike Maramureș, never decided to accept the alternative of self-colonization.

Once again, this arrangement held up - at least in part - after 1918. Although Tisza's person murdered at October 31, 1918 by a group of soldiers - was never again the main rallying point of political currents, Bernády’s experience as middleman and interlocutor between center and periphery served Târgu Mureș well in the coming decades. He spent the revolutionary times in Budapest and returned only in 1919. Meanwhile, in the Hungarian politics, he aligned himself with István Bethlen, erstwhile opponent of Tisza and key leader of the Transylvanian Alliance, and soon-to-become prime minister of Hungary. Upon arrival in Romania, Bernády restarted his political career, and he never feared to deviate from the main line of Hungarian minority politics. $^{50}$

Most importantly, he held significant positions in the boards of a series of companies ranging from mining to forestry, together with prominent members of the National Liberal Party, which was the party that governed Greater Romania with a few interruptions, from 1922 to 1928 and from 1933 to 1937. In 1925 Budapest and Bucharest decided together to designate Bernády, as a sign of his success as interlocutor between the two capitals, to become the new chair of the Hungarian minority party, but the party leadership refused to abide. Bernády soon left the party and he was rewarded by the liberals with the position of mayor of Târgu Mureș, with him effectively playing the same role as he had played before $1918 .{ }^{51} \mathrm{He}$ was the representative of the center, this time Bucharest, in a politically hostile city, where he, nevertheless, ensured the support from the center to help achieve local goals. His success was demonstrated not only by the celebrations at his $70^{\text {th }}$ birthday ${ }^{52}$ and by contemporaneous statistics, but also by his fond memory in posterity.

\section{Brașov: the majority as minority}

\footnotetext{
${ }^{49}$ Fodor, Bernády, pp. 109-128.

${ }^{50}$ Bárdi, Otthon, pp. 148-162.

${ }^{51}$ Ibid.; Fodor, Bernády, pp. 126-129, 144-195.

${ }^{52}$ Fodor, Bernády, pp. 201-206.
} 
The most intriguing of the three models is, however, the last, the one that developed in Brașov around 1910. It was undeniably the outcome of the peculiarities of the city and the Saxon inhabited area. The political and economic system of the dualism favored the Saxons just as much as the Hungarians, and the local Saxon leaders were less concerned about the emergence of a Romanian middle class as were their peers in Sibiu (Nagyszeben, Herrmannstadt). The social and political hierarchy of the city was stale throughout the dualism, with the Saxon financial system resolving most of the problems of the import of capital, and the informal compromise between the government and the Saxon People's Party in 1890 ensured political support from Budapest, too. ${ }^{53}$ The Saxons were able to finance their own development plans mostly without the support of the government; what they needed was administrative goodwill and tolerance, and they recieved it in exchange for political support in the parliament. The embodiment of this political compromise in Brașov was a local electoral pact between the Saxon party and the Hungarian elite in 1900, who divided among them the four electoral constituencies of the county and the seats in the county congregation. Three of the parliamentary seats were accorded to Saxon MPs, and one, the city of Braşov, was accorded to a Hungarian. As the predominant majority of the electorate were Hungarians or Saxons they could comfortably count on to fend off any electoral challenge from Romanian candidates and from rogue Saxons and Hungarians, too. ${ }^{54}$

But the fall of the anti-Tisza coalition government had its reverberations here as well. The local Hungarian politicians previously supported the coalition, and even in the disastrous 1910 elections they could have elected to the parliament József Szterényi, a moderate opposition MP and state secretary in the Ministry of Commerce of the coalition government. Still, they had to rely on the resources channeled by the state. The new Lord Lieutenant came from Tisza's party and he announced the establishment of a local chapter of the Party of National Work. ${ }^{55}$

\footnotetext{
${ }^{53}$ Egry Gábor, Ein anderer Ausgleich, Einiges zur Vorgeschichte des Sachsentages 1890, Zeitschrift für Siebenbürgische Landeskunde 100 (2006), pp. 51-61; Egry, Nemzeti védgát.

${ }^{54}$ Egry Gábor, Tradíció és alkalmazkodás: az erdélyi szászok politikai kultúrája a dualizmus idején, in: Múltunk 48 (2003) 2, pp. 112-158; Enikő Dácz, Auf der Spur interethnischer Beziehungen in drei siebenbürgischen Zeitungen am Anfang des 20. Jahrhunderts, in: Donau-Institut Working Paper Nr. 6 (2013); National Széchényi Library, Apáthy István hagyaték, Quart. Hung. 2456 Zakariás János to István Apáthy, 7. January 1918.

${ }^{55}$ Szele Béla, Gondolkozzunk! Brassói Lapok 27. March 1910; Tudósítás a Végrehajtó Bizottság üléséröl 1910. március 29-én. Brassói Lapok, 30. March 1910; Béke a magyarság körében, Brassói Lapok, 1. April 1910; Dr. W. I. [Weisz Ignác]: A brassói magyarság ügye, Brassói Lapok, 2. April 1910; Dr. W I.: Prodomo, Brassói Lapok, 18. April 1910; A brassói magyar választópolgárok gyülése, Brassói Lapok, 3. April 1910.; Dr. W. I.: A magyarság
} 
The local Hungarian politicians immediately realized that they did not have the necessary resources to uphold a separate party organization and compete with the government sponsored one. Therefore, they decided to start negotiations to find a place for themselves. But in order to strengthen their position, they established a so-called United Hungarian Executive Committee from Brașov that emphasized the necessity of national unity in the city dominated by Saxons and Romanians. It did not last too long that they agreed to the one condition the Lord Lieutenant set: eviction of a fellow member from the Committee, who physically insulted in the parliament prime minister Károly Khuen-Hédervéry in early 1910. After they complied, the Lord Lieutenant, Count Zsigmond Mikes, readily accepted the role of the patron of the newly founded United Hungarian Civic Party of Brașov. ${ }^{56}$

The agreement was simple: every political party was dissolved and their members joined the new organization that was the sole representative of every Hungarian in the city. The new party promised to abandon so-called party politics and emphasized instead national unity. Therefore, it made an attempt to integrate lower middle class and working class Hungarians, too - a move hardly surprising given the social profile of the Hungarian inhabitants of the city. But the party not only paid lip service to this inclusion, its larger representative bodies were filled with members from these social strata, such as locksmiths, railway employees, postal employees, etc. ${ }^{57}$

The idea of national unity was already a strong indication of the nature of the party: it was a minority party, and the program reinforced this impression. The main goal of the organization was not political, but rather organizational: to unite in one organization every Hungarian irrespective of political views and social background, and to organize Hungarian life in the city. Thus, the party was more like a cultural association that organized commemorations of historical events, cultural venues on the occasions of feasts, and was a representative of special economic interests. ${ }^{58}$

\footnotetext{
pártalakulásának kérdéséhez, Brassói Lapok, 15. May 1910; A Brassói Magyar Polgári Párt alakuló értekezlete, Brassói Lapok, 4. June 1910; Zakariás János doktor lemondása, Brassói Lapok, 2. September 1910; A Brassói Magyar Végrehajtó Bizottság ülése 28. November 1910. Brassói Lapok, 29. November 1910.

${ }^{56}$ A Brassói Magyar Végrehajtó Bizottság ülése, Brassói Lapok, 29. November 1910; A Brassói Egységes Magyar Párt megalakulása, Brassói Lapok, 2. December 1910.

${ }^{57}$ A Brassói Egységes Magyar Párt megalakulása, Brassói Lapok, 2. December 1910.

${ }^{58}$ Brassói Egységes Magyar Párt végreható bizottságának első ülése, Brassói Lapok, 3. December 1910.
} 
The party swiftly replaced the former Hungarian parties as the partner of the Saxons in the political pact they had. Szterényi happily joined the party, too, not least because it made him a semi-official government MP instead of being in opposition, without demonstratively abandoning his previous party adherence. He declared himself to be a member of the party, and he also welcomed the national unity expressed by the party, that was to be - according to him - a model for Hungarians in all Transylvania, and even in Hungary as a whole. ${ }^{59}$ Szterényi’s membership was all the more important, because, after Tisza's fall in 1917, he once again became state secretary and, as such, also an important interlocutor, ${ }^{60}$ much like Bernády had been for Târgu Mureș. However, contrary to the center-periphery arrangements in Maramureș or Târgu Mureș, the one in Brașov could not survive 1918. While the key figures remained in Romania in this case as well, the local Hungarians had nothing to offer to the new, Romanian state which was more eager to compromise with the Saxons. The Hungarian Civic Party of Braşov disappeared without announcing its dissolution, but its leaders resurfaced in the Hungarian minority party as its local leaders, ${ }^{61}$ drawing lessons from their earlier experiences with a minority party regarding the proper, unitary organization of a national minority.

\section{Dissociating the nation-state and the bottom-up empire?}

The three cases above illustrate that Hungary around 1900 was not entirely the unitary nationstate it pretended to be. The central government informally exerted differentiated rule over the peripheries, and in this process, it co-opted local elites or employed imperial figures as interlocutors. Furthermore, these informal rearrangements of center-periphery relations were more than unique cases, at least in the sense that they illustrate a systemic characteristic of Hungary: the potential for deviating from the formal rules of unitary administration informally. It is notable that two out of these three cases (Maramureș and Brașov) were part of a decades-long informal settlement between regional elites and the central government - between Maramureș nobility and Saxon leaders. Their reconfirmation or reconfiguration around 1900 was not just a mere coincidence, however. They were the results of an imperial context that most

\footnotetext{
${ }^{59}$ Szterényi József, Az új alakulat, Brassói Lapok, 1. January 1911.

${ }^{60}$ See Balaton Petra, Szterényi József erdélyi pályafutása, in: Levéltári Közlemények 82 (2011), pp. $146-170$.

${ }^{61}$ György Béla, A romániai Országos Magyar Párt története 1922-1938, PhD-disszertáció, Budapest 2003.
} 
contemporaries understood as a crisis and which generated a series of reform projects and attempts, like A. C. Popovici's Grossösterreich plans, the centralization ideas from archduke Franz Ferdinand, or even the Austromarxist national autonomy proposals. It is also telling that since the last years of the 19th century imperial and provincial legislation tried to address the imperial crises, too, with extension of suffrage, or with the provincial compromises. ${ }^{62}$

Hungary was often not part of these plans because of its unique position and unitary character that the Hungarian elite was not yet ready to abandon, and nor had it seen any meaningful legislation to reduce the growing social tensions. Nevertheless, these political attempts that aimed at reconfiguring center-periphery relations within the country were bound to the crisis. The Maramureș model aimed at preserving a fine balance within a multi-ethnic nobility in order to eliminate national conflict, and it achieved this aim with well-proven, traditional means. The other two attempts, however, at least in part, were reactions to the challenges posed by the national movements and the failures of modernization. Therefore they did not rely on the traditions of a society still shaped by its feudal legacy; rather, they tried to invent new models of center-periphery relations.

But even though, just like in Cisleithania, they have grown out of national conflict, their goals were very different. Regionalists in Transylvania and Hungarian leaders in Braşov did not aim at securing or extending the rights of the nationalities or establishing national autonomy. Their concern was quite different - that of the preservation of Hungarian dominance within Hungary. The peculiarity of these cases lies exactly in this characteristic, as they wanted to relax the unitary nature of the Hungarian nation state in order to preserve its national character. Or, to put it more provocatively: while in Cisleithania reform ideas tended to promote a nationalization of the empire, in Hungary rather dismantling of and dissociation from the nation state was their trend. Given how much the successor states have struggled with similar problems, and how often they employed the same methods (and sometimes even the same people) to resolve these problems, at least temporarily, Hungary's experiment with its center-periphery relations can be understood as a precursor for the post-Habsburg quasi- or mini-empires. ${ }^{63}$

\footnotetext{
${ }^{62}$ Heir/Wimmer, Is nationalism; Judson, The Habsburg; Börries Kuzmany, Habsburg Austria: Experiments in NonTerritorial Autonomy, in: Ethnopolitics, 15 (2016) 1, pp. 43-65

${ }^{63}$ Judson, The Habsburg; Egry Gábor, Etnicitás, identitás, politika. Magyra kisebbségek nacionalizmus és regionalizmus között Romániában és Csehszlovákiában 1918-1944, Budapest 2015.
} 
The three cases offer important lessons for those who wish to grasp Austria-Hungary as an imperial unity, as well. While neither of these cases has revealed top-down transmission of the imperial ideas, they still speak of an imperial character of Hungary - the component state of the Habsburg Empire that is often simply taken as a nation state. Thus, tentatively, it seems that a different approach - the opposite perspective - would be more suitable for a comprehensive analysis of the empire as a whole. It is true, that from such a perspective Austria-Hungary looks more structured than an empire is usually assumed to be. It is not just a single (or two) metropolitan centers with their peripheries, but rather a more structured, and more uneven system of relations between centers and regions and between these regions, too. Looking at how certain regions and localities were related to the centers and to other regions could offer a chance to reconstruct the empire from below and to overcome the duality so often reflected in the literature: the co-existence of a complex, imperial Cisleithania and a unitary Hungarian nation state. 